\title{
Immunomodulatory Effect of Active Treatment Options in Food Allergy
}

\author{
Robbie D. Pesek, $M D^{*}$ \\ Stacie M. Jones, MD
}

\author{
Addrress \\ *University of Arkansas for Medical Sciences and Arkansas Children's Hospital, \\ 13 Children's Way, Slot 512-13, Little Rock, AR 72202, USA \\ Email: rdpesek@uams.edu
}

Published online: 14 March 2014

(C) Springer International Publishing AG 2014

Keywords Oral immunotherapy - OIT - Sublingual immunotherapy - SLIT - Epicutaneous immunotherapy - EPIT . Oral tolerance - Sustained unresponsiveness - Omalizumab - Chinese herbal therapy · Food allergy

\section{Opinion statement}

The gastrointestinal tract is the largest immune organ in the body and relies on a variety of mechanisms to handle the constant exposure of ingested antigens and commensal bacteria. Tolerance to ingested food proteins is the default response; however, there are a variety of both host and food-related factors that can lead to loss of tolerance and development of food allergy. Although many children will outgrow their food allergies, a significant number will continue to require life-long avoidance. Currently, there are no FDA-approved treatments for food allergies; however, multiple therapies have been or are currently under investigation and more are on the horizon. The most studied modalities include oral (OIT) and sublingual (SLIT) immunotherapy. Both are successful in desensitizing patients to food allergens, reducing the risk of reaction following accidental exposure, and there is some evidence for induction of short-term tolerance as well. (Table 1) Emerging therapies include combining OIT with a monoclonal anti-IgE molecule, Chinese herbal therapy, and epicutaneous immunotherapy (EPIT), all of which have yielded promising early results. There are other targeted therapies currently in pre-clinical development. At this time, none of these options are ready for clinical use; and more work is needed to develop safe and effective therapies.

\section{Introduction}

The gastrointestinal (GI) tract is regularly exposed to potentially harmful antigens through ingested foods as well as commensal bacterial [1]. Following inges- tion, food proteins are digested and then absorbed by intestinal epithelial cells in forms including dipeptites, tripeptides, and amino acids. During this 
process, food proteins interact with components of the immune system, both in the intestinal lumen as well as in nearby lymphoid tissues. These interactions determine whether the body develops tolerance or reactivity to ingested food proteins. Oral tolerance is defined as antigenic suppression of the cellular or humoral immune response that occurs in the gut, and this is the typical response that occurs when food is ingested [2•]. Food allergies are believed to arise when the normal mechanisms that promote oral tolerance are interrupted or delayed (Table 1).

\section{The GI tract and generation of oral tolerance}

- Immune cells are located in three primary areas throughout the GI tract: the mucosal epithelium, lamina propria, and the gut-associated lymphoid tissue (GALT), which is made up of lymphoid follicles, Peyer's patches, and the appendix. Mucosal epithelium can serve as a physical barrier to prevent the exposure of potentially harmful antigens to underlying lymphoid tissues and this is primarily achieved through adherens and tight junctions. Gut epithelium also expresses MHC Class II molecules that lack traditional co-stimulatory molecules, thus promoting tolerance after binding to food proteins, rather than reactivity [3]. Peyer's patches contain organized lymphoid follicles consisting of a B-cell germinal center surrounded by $\mathrm{T}$ lymphocytes. The lamina propria also contains a significant number of $\mathrm{B}$ cells which in the GI tract serve as an important source of IgA production. Secretory IgA produced by these $\mathrm{B}$ cells is present in the intestinal lumen and binds to food proteins, preventing absorption by the gut epithelium and possible reactivity [4].

- One of the most important cells for generating tolerance to ingested food proteins is the dendritic cell (DC) [5]. There are two types of gut DCs, those that express CD103 and those that express CX3CR1 [6]. CD103+ DCs are nonmigratory, while those that express CX3CR1 are able to migrate to regional lymph nodes. DCs can interact with food proteins in several different ways: by extending dendrites between

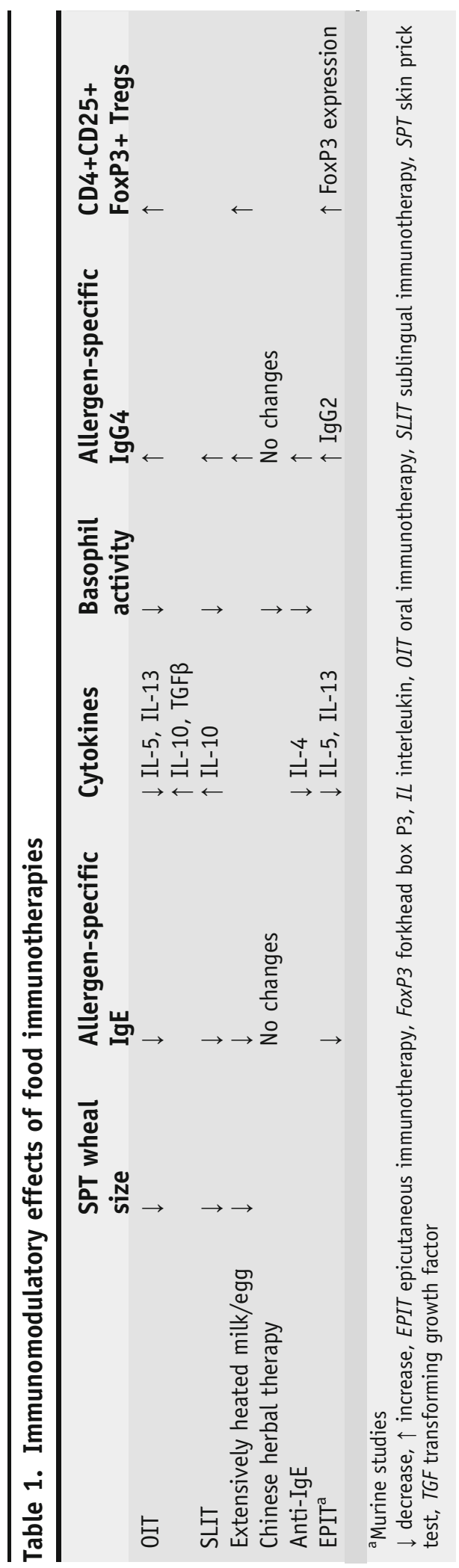


epithelial cells to sample luminal contents, by interacting with epithelial cells directly, or through uptake in Peyer's patches. Once antigen is taken up by DCs it is presented to B cells in Peyer's patches or T cells in regional lymph nodes. Under normal circumstances, and in the presence of transforming growth factor (TGF)- $\beta$ and retinoic acid, DCs promote the development of regulatory T cells [7-9]. DCs also secrete the cytokine interleukin (IL)-10, which aids in the development of oral tolerance.

- Regulatory T cells (Tregs) also play a critical role in the development of oral tolerance. Tregs function to actively suppress the immune response, which is critical in preventing inappropriate reactivity. There are two primary classes of Tregs, including natural Tregs (nTreg) that express the forkhead box P3 (FoxP3) protein and are produced in the thymus, and inducible Tregs (iTreg) which are produced after antigenic stimulation $[10,11]$. FoxP3 acts to suppress $T$ helper $\left(T_{h}\right) 1$ and $T_{h} 2$ immune responses and a lack of FoxP3 is associated with a syndrome of immunodysregulation, polyendocrinopathy, and enteropathy that is Xlinked (IPEX), and is characterized by severe autoimmunity [12]. Inducible Tregs are more important for the development of oral tolerance and can be further divided into three subsets: $T_{h} 3 T$ cells, $T_{R} 1 T$ cells, and inducible $\mathrm{CD} 4+\mathrm{CD} 25+$ FoxP3 $+\mathrm{T}$ cells. $\mathrm{T}_{\mathrm{R}} 1$ cells provide immune suppression primarily through secretion of IL-10 and, while $\mathrm{T}_{\mathrm{h}} 3$ cells also secrete IL10 , they produce immune-suppressing activity through TGF- $\beta$ [13-15]. TGF- $\beta$ also enhances the development of tolerogenic DCs, which in turn promotes the conversion of naive $T$ cells to Tregs and B-cell class switching from production of IgM to IgA [16•]. Inducible CD4+CD25+ Tregs also secrete TGF- $\beta$ and are found in higher numbers in children that have outgrown their milk allergy compared with those who continue to be milk allergic, suggesting their importance in the development of oral tolerance [17-19].

- In addition to regulatory T cells, IgA-producing B cells, and DCs, CD8+ suppressor T cells, gamma-delta T cells, natural killer T (NKT) cells, and the cytokine thymic stromal lymphopoetin (TSLP) are believed to have a role in oral tolerance induction [20-22].

\section{Mechanisms of food allergy}

- Food allergy is a $T_{h} 2$ response mediated through allergen-specific CD4+ T cells and generation of cytokines including IL-4, IL-5, and IL-13. These cytokines activate B cells to increase allergen-specific IgE production that can bind to the high-affinity IgE receptor (FcER1) on mast cells and basophils [23]. When re-exposed to the allergen, these cells produce histamine, prostaglandins, leukotrienes, and more $\mathrm{T}_{\mathrm{h}} 2$ cytokines leading to clinical symptoms of food allergy, including anaphylaxis. Despite the wide variety of food proteins that the GI tract is exposed to, only a few account for the majority of food allergies, including cow's milk, hen's egg, soy, wheat, peanuts, tree nuts, fish, and shellfish. Of these, peanuts, tree nuts, fish and shellfish are most likely to persist into adulthood [24, 25••].

- There are multiple factors involving the host GI tract and immune system as well as characteristics of food proteins themselves that can lead to reactivity rather than tolerance. (Table 2) In general, food proteins are typically broken down by digestive enzymes and gastric acid which destroys conformational epitopes, making food proteins less recognizable by the gut immune system. Resistance to heat denaturing, water solubility, the presence of glycosylation residues and/or linear epitopes, and molecular weight less than 70 kilodaltons $(\mathrm{kD})$ all increase the allergenicity of food proteins [15]. Antacids also increase the risk of reactivity as food proteins are less broken down and are presented more intact to the lower GI tract [26]. Timing, dose, and route of exposure of food proteins is also important. Several studies suggest that delayed introduction to peanut and wheat increases the risk of allergy to these foods [27-29]. Infants with atopic dermatitis, but no history of peanut allergy, who are exposed to peanut oil through their skin are at higher risk 
Table 2. Factors important for the development of oral tolerance versus food allergy

\section{Oral tolerance}

- Intact gut epithelial barrier

- Acid degradation of food proteins leading to destruction of conformational epitopes

- Promotion of Treg development by dendritic cells

- Treg production of IL-10 and TGF $\beta$

- IgA binding to food proteins to prevent absorption

- Commensal gut flora
IgE-mediated food allergy

- Immature gut barrier leading to increased permeability

- Resistance to acid destruction, molecular weight $<70 \mathrm{kD}$, glycosylation residules, linear epitopes, water solubility, use of antacids

- $\mathrm{T}_{\mathrm{h}} 2$ cytokines (IL-4, IL-5, IL-13)

- Destruction of commensal gut flora of developing peanut allergy [30].

- Gut permeability also appears to play a significant role in the balance between tolerance and reactivity. After birth, the permeability of the gut epithelial barrier is high and may take several years to fully develop. During this time, more food proteins may be exposed to gut lymphoid tissues, increasing the risk of reactivity [15]. Breast feeding also appears to promote immune tolerance. Breast milk IgA is resistant to breakdown by oral enzymes and gut acidity and can provide passive immunity against ingested food antigens and bacteria. There may be other factors in breast milk that can promote the maturity of the GI epithelial barrier [31]. In IgA-deficient patients, the lack of secretory IgA may also lead to increased uptake of food allergens through gut epithelium and a higher risk of developing food allergy [32-34]. The colonization of the gut with commensal flora is also very important as interactions between gut flora and $\mathrm{T}$ cells promote the normal development of gut lymphoid tissues as well as generation of Tregs [35]. If gut flora is disturbed, the normal mechanisms that promote oral tolerance do not occur and food allergy can result. Genetic factors also likely play a role in the risk of food allergy; however, there are no conclusive human studies [36].

\section{Treatment options}

\section{Immunotherapy for treatment of food allergy}

- A significant number of patients will outgrow their food allergies but this process may take years. Approximately $11 \%$ of children will outgrow their cow's milk allergy and $19 \%$ will outgrow their egg allergy by age 4 , although it may occur sooner in some populations. While these numbers increases to nearly $80 \%$ by age 16 , only $20 \%$ will have outgrown their peanut allergy by this same time, suggesting that food allergies can be a long-term or even life-long problem for many [37-42]. Immunotherapy is effective in the treatment of both pollen and venom-induced allergies and it is hypothesized that the same may hold true for food allergic patients [43, 44].

- The goals of food immunotherapy are to induce a state of desensitization as well as immune tolerance. Desensitization is defined as an increase in the dose of food allergen required to induce an allergic 
reaction. It requires continuous exposure to the allergen or the likelihood of a reaction following future ingestion of the food is high. Tolerance represents a long-term immune change that allows for the ingestion of a food allergen without the need for continuous exposure. Another concept is that of 'sustained unresponsiveness', which represents short-term tolerance. In studies of oral immunotherapy, sustained unresponsiveness occurs following treatment when patients can ingest food ad libitum. Desensitization can be induced in a relatively short amount of time, typically months, while sustained unresponsiveness and/or tolerance may take a significantly longer period to achieve. Investigations are underway to determine the possibility of long-term reversibility of the allergenic state to specific foods following treatment with immunotherapy.

- Oral immunotherapy (OIT) uses a protein powder mixed with other foods that the subject ingests. It is believed that OIT activates gut DCs, promoting immune tolerance rather than reactivity [15]. Treatment with OIT involves three phases. The first is escalation, during which subjects are given 6-8 doses of the food allergen in incremental doses and in rapid succession, usually during one day. This is followed by the buildup phase, when subjects ingest a daily dose of the food allergen. This is increased every 1-2 weeks until a target dose is reached, usually months. The last phase is maintenance, during which subjects ingest a stable, daily dose of the food allergen for a scheduled amount of time, often months to years. Following these phases, oral food challenges (OFCs) are typically performed to assess for the development of desensitization, sustained unresponsiveness, and/or tolerance.

- OIT studies have been conducted for milk, egg, and peanut and are in progress with tree nuts and multiple foods in a single dose [45-50, $51 \bullet, 52 \bullet \bullet, 53-57,58 \bullet, 59 \bullet \bullet$. OIT appears efficacious at desensitizing subjects to their respective food allergen, and some studies have also shown the ability to induce sustained unresponsiveness in a subset of subjects; however, long-term tolerance remains elusive. Because of this, more work is needed before OIT is ready for widespread clinical use $[60 \bullet, 61 \bullet, 62,63 \bullet, 64 \bullet]$.

- In regards to immune modulation, OIT reduces skin prick test (SPT) wheal size, allergen-specific IgE levels, and basophil activity [45, $52 \bullet \bullet, 54,56,57,58 \bullet, 59 \bullet \bullet$ ]. OIT also increases allergen-specific IgG4, a marker associated with tolerance development in other forms of immunotherapy (such as subcutaneous immunotherapy [SCIT]).

- In a study of six egg-allergic subjects, OIT led to increases in IL-10 and TGF- $\beta$ as well as the development of CD4+CD25+ regulatory T cells [55]. Similar results were seen in a study of 29 peanut-allergic subjects who were treated with OIT for 36 months [56]. Increases in 
pro-inflammatory cytokines including IL-1 $\beta$, IL-5, and tumor necrosis factor (TNF)- $\alpha$ were seen, suggesting a shift away from a $\mathrm{T}_{\mathrm{h}} 2$ profile. In a study by Varshney et al. [57], peanut-allergic subjects were randomized to receive OIT or placebo. Subjects receiving OIT had increased numbers of CD4+CD25+FoxP3+ T cells at the end of therapy and these subjects also had significant decreases in IL-5 and IL-13 levels compared with baseline. There were no changes in IL-10 or interferon (IFN)- $\gamma$ levels in either group. TGF- $\beta$ increased initially, but returned to baseline levels by the end of the study. OIT-treated subjects also had reduced binding of IgE to Ara h 1 and Ara h 3 epitopes as well as increased IgG4 binding to Ara h 2, which mimics immunologic findings associated with the development of natural tolerance to peanut $[58 \bullet$.

- In a study by Keet et al. [51•], 30 milk-allergic subjects received sublingual immunotherapy (SLIT) buildup after which they were randomized to continue SLIT or transition to milk OIT for a total of 60 weeks. Although the study did not include analysis of Treg development, 8 of 20 OIT subjects were still able to tolerate milk products 6 weeks after therapy was stopped, suggesting sustained unresponsiveness. Responders also exhibited decreased milk-specific IgE and increases in IgG4. Sustained unresponsiveness has also been demonstrated with egg OIT; nearly $30 \%$ of egg-allergic subjects treated with 22 months of egg OIT were able to pass an OFC 4-6 weeks after

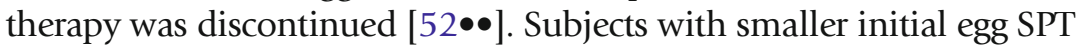
wheal size and those who exhibited increases in egg-specific IgG4 levels during treatment were more likely to develop sustained unresponsiveness. Similar results were seen by Vickery et al. [59••] in a trial of peanut OIT. Of the 24 subjects who received up to 5 years of OIT, half were able to pass a peanut OFC 1 month after therapy was stopped. The best predictors for achieving sustained unresponsiveness were a lower ratio of peanut-specific total IgE and lower Ara h 2-specific IgE levels. There was no significant difference between responders and non-responders in regards to peanut-specific IgG4 levels or numbers of CD4+CD25+FoxP3+ T cells at the end of therapy.

Sublingual immunotherapy

- SLIT uses a liquid concentrate of an allergen placed under the tongue which is increased over time to achieve a target dose. SLIT is believed to stimulate Langerhans cells in the oral mucosa that downregulate the immune response, possibly through increases in production of IL-10 and TGF- $\beta$ [65]. SLIT has been used effectively in subjects allergic to kiwi, hazelnut, peach, milk, and peanut [51•, 66-69, 70•].

- In a study by Enrique et al. [68], hazelnut-allergic subjects received SLIT for 8-12 weeks. Following treatment, SLIT-treated subjects had increases in hazelnut-specific IgG-4 as well as IL-10 compared with controls. 
- In peanut-allergic subjects, Kim et al. [71] found decreases in peanut SPT wheal size, basophil activity, peanut-specific IgE, and IL-5 levels after 12 months of peanut SLIT. There were significant increases in peanut-specific IgG4 but non-significant increases in numbers of Tregs. Fleischer et al. [72] did not find any significant changes in peanut-specific IgE, IgG4, or basophil activity in subjects receiving up to 68 weeks of peanut SLIT. Treated subjects did have an increase in the amount of peanut protein tolerated during OFC; however, it was not enough to induce clinically relevant protection. While these studies show induced immune changes following SLIT treatment and clinical evidence of desensitization, the ability of SLIT to induce sustained unresponsiveness and/or long-term tolerance has not been well studied and remains in question.

Extensively heated foods

- Heating of milk and egg leads to conformational changes in these proteins with reduced IgE binding to recognized epitopes [73, 74]. These changes allow many milk and egg allergic subjects to ingest extensively heated products. In milk-allergic children, $75 \%$ are able to pass an OFC to baked milk and, in those who add extensively heated milk to their diet, SPT wheal size is smaller and casein-specific IgG4 is higher compared with controls [19, 75]. These subjects also have a higher population of regulatory $\mathrm{T}$ cells than those who cannot tolerate heated milk or even those who have already outgrown their milk allergy. Combined with similar results seen in egg-allergic children, the addition of extensively heated milk or egg appears to hasten the development of tolerance to uncooked products [76, 77].

- Chinese herbal therapies have been used for thousands of years to treat a variety of medical problems. In murine models of food allergy, a nine-herb extract mix (Food Allergy Herbal Formula-2 [FAHF-2]) was able to induce immune changes including decreased $\mathrm{T}_{\mathrm{h}} 2$ cytokine production, IgE levels, and basophil/mast cell number and activation [78, 79]. A phase I study has been completed in human subjects with food allergies to peanut, tree nuts, fish and/or shellfish [80]. Following 6 months of therapy with FAHF-2, treated subjects exhibited decreased basophil activation, but no significant changes in food-specific IgE or IgG4 levels. A phase II study has been completed and results are pending.

Anti-IgE in treatment of food allergy

- Omalizumab, a monoclonal antibody that binds free IgE molecules, is FDA approved for the treatment of allergic asthma but has also 
been studied in food-allergic subjects. It functions by attaching to the $\mathrm{C} 3$ domain of the IgE molecule which prevents binding to the highaffinity IgE receptor, FceR1. This decreases the amount of circulating free-IgE as well as the number of FceR1 receptors on mast cells and basophils [81, 82].

- In studies of peanut-allergy subjects, the use of omalizumab is associated with decreased basophil histamine release (BHR), allowing subjects to consume larger doses of peanut protein during OFC [83]. Omalizumab has also been used in milk-allergic subjects to increase the amount of milk protein tolerated during OIT desensitization and causes deletion of milk-specific CD4+ T cells, decreases in IL-4 production, and increases in milk-specific IgG4 $[84,85]$. Similar results have been seen when omalizumab has been combined with peanut OIT [86].

- Please see the corresponding article in this journal for further details regarding the use and efficacy of anti-IgE molecules in the treatment of food allergy.

- Epicutaneous immunotherapy (EPIT) involves delivery of an allergen through dermal contact with use of an allergen-imbedded patch. Little is known about the immune mechanisms of EPIT in humans, but the mechanism of action as defined in murine studies is believed to be through activation of local Langerhans cells that migrate to regional lymph nodes and downregulate the immune response [87]. In a study of peanut-sensitized mice, the use of EPIT significantly decreased peanut-specific IgE and increased peanut-specific IgG2 compared with sham-treated mice $[88,89]$.

- In humans, preliminary studies involving milk-allergic subjects showed an increase in the dose of milk tolerated after 3 months of treatment compared with controls. Side effects were primarily dermal, including erythema and/or eczema at the patch site [90]. There were no significant changes in cow's milk-specific IgE levels during treatment. A phase I study has been completed for peanut EPIT and there are other ongoing studies in the United States, Canada, and Europe.

\section{Compliance with Ethics Guidelines}

Conflict of Interest

Robbie Pesek declares that he has no conflict of interest.

Stacie Jones declares that she has no conflict of interest.

Human and Animal Rights and Informed Consent

This article does not contain any studies with human or animal subjects performed by any of the authors. 
Papers of particular interest, published recently, have been highlighted as:

- Of importance

$\bullet \quad$ Of major importance

1. Chehade M, Mayer L. Oral tolerance and its relation to food hypersensitivities. J Allergy Clin Immunol. 2005;115:3-12.

2. $\quad$ Berin MC, Mayer L. Can we produce true tolerance in patients with food allergy? J Allergy Clin Immunol. 2013;131:14-22.

This is an excellent review of immune mechanisms involved in food allergy as well as findings from published food immunotherapy studies. It addresses the impact of food immunotherapy and induction of long-term tolerance.

3. Hershberg RM, Cho DH, Youakim A, Bradley MB, Lee JS, Framson PE, et al. Highly polarized HLA class II antigen processing and presentation by human intestinal epithelial cells. J Clin Invest. 1998;102:792-803.

4. Roux ME, McWilliams M, Phillips-Quagliata JM, Lamm ME. Differentiation pathway of Peyer's patch precursors of IgA plasma cells in the secretory immune system. Cell Immunol. 1981;61:141-53.

5. Kraus TA, Brimnes J, Muong C, Liu JH, Moran TM, Tappenden KA, et al. Induction of mucosal tolerance in Peyer's patch-deficient, ligated small bowel loops. J Clin Invest. 2005;115:2234-43.

6. Bogunovic M, Ginhoux F, Helft J, Shang L, Hashimoto D, Greter M, et al. Origin of the lamina propria dendritic cell network. Immunity. 2009;31:513-25.

7. Coombes JL, Siddiqui KR, Arancibia-Carcamo CV, Hall J, Sun CM, Belkaid Y, et al. A functionally specialized population of mucosal CD103+ DCs induces Foxp3+ regulatory T cells via a TGF-beta and retinoic acid-dependent mechanism. J Exp Med. 2007;204:1757-64.

8. Matteoli G, Mazzini E, Iliev ID, Mileti E, Fallarino F, Peccutti P, et al. Gut CD103+ dendritic cells express indoleamine 2,3-dioxygenase which influences $\mathrm{T}$ regulatory/T effector cell balance and oral tolerance induction. Gut. 2010;59:595-604.

9. Lee SW, Park Y, Eun SY, Madireddi S, Cheroutre H, Croft $M$. Cutting edge: 4-1BB controls regulatory activity in dendritic cells through promoting optimal expression of retinal dehydrogenase. J Immunol. 2012;189:2697-701.

10. Sakaguchi S, Sakaguchi N, Asano M, Itoh M, Toda M. Immunologic self-tolerance maintained by activated T cells expressing IL-2 receptor alpha-chains (CD25). Breakdown of a single mechanism of self-tolerance causes various autoimmune diseases. J Immunol. 1995;155:1151-64.

11. Chen W, Jin W, Hardegen N, Lei KJ, Li L, Marinos N, et al. Conversion of peripheral CD4+CD25-naive $\mathrm{T}$ cells to CD4+CD25+ regulatory T cells by TGF-beta induction of transcription factor Foxp3. J Exp Med. 2003;198:1875-86.

12. McMurchy AN, Gillies J, Allan SE, Passerini L, Gambineri E, Roncarolo MG, et al. Point mutants of forkhead box P3 that causes immune dysregulation, polyendocrinopathy, enteropathy, X-linked have diverse abilities to reprogram $\mathrm{T}$ cells into regulatory $\mathrm{T}$ cells. J Allergy Clin Immunol. 2010;126:1242-51.

13. Groux H, O'Garra A, Bigler M, Rouleau M, Antonenko S, de Vries JE, et al. A CD4+ T-cell subset inhibits antigen-specific T-cell responses and prevents colitis. Nature. 1997;389:737-42.

14. Chen Y, Kuchroo VK, Inobe JI, Hafler DA, Weiner HL. Regulatory $\mathrm{T}$ cell clones induced by oral tolerance: suppression of autoimmune encephalomyelitis. Science. 1994;265:1237-40.

15. Vickery BP, Scurlock AM, Jones SM, Burks AW. Mechanisms of immune tolerance relevant to food allergy. J Allergy Clin Immunol. 2011;127:576-84.

16. Palomares O. The role of regulatory T cells in IgEmediated food allergy. J Investig Allergol Clin Immunol. 2013;23:371-82.

This is another excellent review of regulatory $\mathrm{T}$ cells and their role in food allergy and tolerance induction.

17. Hadis U, Wahl B, Schulz O, Hardtke-Wolenski M, Schippers A, Wagner $\mathrm{N}$, et al. Intestinal tolerance requires gut homing and expansion of Foxp3+ regulatory $\mathrm{T}$ cells in the lamina propria. Immunity. 2011;34:237-46.

18. Karlsson MR, Rugtveit J, Bradtzaeg P. Allergen-responsive CD4+CD25+ regulatory $\mathrm{T}$ cells in children who have outgrown cow's milk allergy. J Exp Med. 2004;199:1679-88.

19. Shreffler WG, Wanich N, Moloney M, NowakWegrzyn A, Sampson HA. Association of allergenspecific regulatory $\mathrm{T}$ cells with the onset of clinical tolerance to milk protein. J Allergy Clin Immunol. 2009;123:43-52.

20. Faria AH, Weiner HL. Oral tolerance. Immunol Rev. 2005;206:232-59.

21. Ziegler SF, Artis D. Sensing the outside world: TSLP regulates barrier immunity. Nat Immunol. 2010;11:289-93.

22. Middendorp $S$, Nieuwenhuis EE. NKT cells in mucosal immunity. Mucosal Immunol. 2009;2:393402.

23. Sampson HA, Burks AW. Adverse reactions to foods. In: Adkinson NF, Busse WW, Bochner BS, Holgate ST, 
Simons ER, Lemanske RF, editors. Middleton's allergy: principles and practice. 7 th ed. Philadelphia: Elsevier; 2009. p. 1139-68.

24. Wood RA. The natural history of food allergy. Pediatrics. 2003;111:1631-7.

25.• Boyce JA, Assa'ad A, Burks AW, Jones SM, Sampson HA, Wood RA, et al. Guidelines for the diagnosis and management of food allergy in the United States: report of the NIAID-sponsored expert panel. J Allergy Clin Immunol. 2011;127:576-84.

The guidelines published by the NIAID are critical for healthcare professionals that treat patients with food allergy and provide a comprehensive tool for understanding the diagnosis and management of food allergies.

26. Untersmayr E, Jensen-Jarolim E. The role of protein digestibility and antacids on food allergy outcomes. J Allergy Clin Immunol. 2008;121:1301-8.

27. Du Toit G, Katz Y, Sasieni P, Mesher D, Maleki SJ, Fisher HR, et al. Early consumption of peanuts in infancy is associated with a low prevalence of peanut allergy. J Allergy Clin Immunol. 2008;122:984-91.

28. Poole JA, Barriga K, Leung DY, Hoffman M, Eisenbarth GS, Rewers M, et al. Timing of initial exposure to cereal grains and the risk of wheat allergy. Pediatrics. 2006;117:2175-82.

29. Fox AT, Sasieni P, du Toit G, Syed H, Lack G. Household peanut consumption as a risk factor for the development of peanut allergy. J Allergy Clin Immunol. 2009;123:417-23.

30. Lack G, Fox D, Northstone K, Golding J. Factors associated with the development of peanut allergy in childhood. N Engl J Med. 2003;348:977-85.

31. Gdalevich M, Mimouni D, David M, Mimouni M. Breast-feeding and the onset of atopic dermatitis in childhood: a systematic review and meta-analysis of prospective studies. J Am Acad Dermatol.

2004;45:520-7.

32. Brandtzaeg P. Update on mucosal immunoglobulin A in gastrointestinal disease. Curr Opin Gastro. 2010;26:554-63.

33. Johansen FE, Pekna M, Norderhaug IN, Haneberg B, Hietala MA, Kraici P, et al. Absence of epithelial immunoglobulin A transport, with increased mucosal leakiness, in polymeric immunoglobulin receptor/ secretory component-deficient mice. J Exp Med. 1999;190:915-21.

34. Karlsson MR, Johansen FE, Kahu H, Macpherson A, Bradtzaeg P. Hypersensitivity and oral tolerance in the absence of a secretory immune system. Allergy. 2010;65:561-70.

35. Mowat A, Parker L, Beacock-Sharp H, Millington OR, Chirdo F. Oral tolerance: overview and historical perspectives. Ann N Y Acad Sci. 2004;1029:1-8.

36. van den Oord R, Sheikh A. Filaggrin gene defects and risk of developing allergic sensitization and allergic disorders systematic review and meta-analysis. BMJ. 2009;339:b2243.
37. Savage JH, Matsui EC, Skripak JM, Wood RA. The natural history of egg allergy. J Allergy Clin Immunol. 2007;120:1413-7.

38. Skripak JM, Matsui EC, Mudd K, Wood RA. The natural history of IgE-mediated cow's milk allergy. J Allergy Clin Immunol. 2007;120:1172-7.

39. Oranje AP, Wolkerstorfer A, de Waard-van der Spek FB. Natural course of cow's milk allergy in childhood atopic eczema/dermatitis syndrome. Ann Allergy Asthma Immunol. 2002;89:52-5.

40. Cantani A, Micera M. Natural history of cow's milk allergy. An eight-year follow-up in 115 atopic children. Eur Rev Med Pharmacol Sci. 2004;8:153-64.

41. de Boissieu D, Dupont C. Natural course of sensitization to hen's egg in children not previously exposed to egg ingestion. Eur Ann Allergy Clin Immunol. 2006;38:113-7.

42. Peters RL, Dharmage SC, Gurrin LC, Koplin JJ, Ponsonby AL, Lowe AJ, et al. The natural history and clinical predictors of egg allergy in the first 2 years of life: A prospective, population-based cohort study. J Allergy Clin Immunol. 2014;133:485-91.

43. Abramson MJ, Puy RM, Weiner JM. Injection allergen immunotherapy for asthma. Cochrane Database Syst Rev. 2010;8, CD001186.

44. Bonifazi F, Jutel M, Bilo BM, Birnbaum J, Muller U, the EAACI Interest Group on Insect Venom Hypersensitivity. Prevention and treatment of hymenoptera venom allergy: guidelines for clinical practice. Allergy. 2005;60:1459-70.

45. Skripak JM, Nash SD, Rowley H, Brereton NH, Oh S, Hamilton RG, et al. A randomized, double-blind, placebo-controlled study of milk oral immunotherapy for cow's milk allergy. J Allergy Clin Immunol. 2008;122:1154-60.

46. Garcia-Ara C, Pedrosa M, Belver MT, MartinMunoz MF, Quirce S, Boyan-Martinez T. Efficacy and safety of oral desensitization in children with cow's milk allergy according to their serum specific IgE level. Ann Allergy Asthma Immunol. 2013;110:290-4.

47. Longo G, Barbi E, Berti I, Meneghetti R, Pittalis A, Ronfani $\mathrm{L}$, et al. Specific oral tolerance induction in children with very severe cow's milk-induced reactions. J Allergy Clin Immunol. 2008;121:343-7.

48. Pajno GB, Caminiti L, Ruggeri P, De Luca R, Vita D, La Rosa M, et al. Oral immunotherapy for cow's milk allergy with a weekly up-dosing regimen: a randomized single-blind controlled study. Ann Allergy Asthma Immunol. 2010;105:376-81.

49. Keet CA, Seopaul S, Knorr S, Narisety S, Skripak J, Wood RA. Long-term follow-up of oral immunotherapy for cow's milk allergy. J Allergy Clin Immunol. 2013;132:737-9.

50. Salmivesi S, Korppi M, Makela MJ, Paassilta M. Milk oral immunotherapy is effective in school-aged children. Acta Paediatr. 2013;102:172-6. 
51. Keet CA, Fischmeyer-Guerrerio PA, Thyagarajan A, Schroeder JT, Hamilton RG, Boden S, et al. The safety and efficacy of sublingual and oral immunotherapy for milk allergy. J Allergy Clin Immunol. 2012;129:448-55.

This is an excellent study that directly compares OIT and SLIT for the treatment of milk allergy.

52.• Burks AW, Jones SM, Wood RA, et al. Oral immunotherapy for treatment of egg allergy in children. $\mathrm{N}$ Engl J Med. 2012;367:233-43.

This seminal study by Burks et al. is one of the first to show that OIT can induce sustained unresponsiveness in egg-allergic patients.

53. Blumchen K, Ulbricht H, Staden U, Dobberstein K, Beschorner J, de Oliveira LC, et al. Oral peanut immunotherapy in children with peanut anaphylaxis. J Allergy Clin Immunol. 2010;126:286-91.

54. Thyagarajan A, Jones SM, Calatroni A, Pons L, Kulis $\mathrm{M}$, Woo CS, et al. Evidence of pathway-specific basophil anergy induced by peanut oral immunotherapy in peanut-allergic children. Clin Exp Allergy. 2012;42:1197-205.

55. Vickery BP, Pons L, Kulis M, Steele P, Jones SM, Burks AW. Individualized IgE-based dosing of egg oral immunotherapy and the development of tolerance. Ann Allergy Asthma Immunol. 2010;105:444-50.

56. Jones SM, Pons L, Roberts JL, Scurlock AM, Perry TT, Kulis $M$, et al. Clinical efficacy and immune regulation with peanut oral immunotherapy. J Allergy Clin Immunol. 2009;124:292-300.

57. Varshney P, Jones SM, Scurlock AM, Perry TT, Kemper A, Steele P, et al. A randomized controlled study of peanut oral immunotherapy: clinical desensitization and modulation of the allergic response. J Allergy Clin Immunol. 2011;127:654-60.

58. Vickery BP, Lin J, Kulis M, Fu Z, Steele PH, Jones SM, et al. Peanut oral immunotherapy modifies IgE and IgG4 responses to major peanut allergens. J Allergy Clin Immunol. 2013;131:128-34.

This study by Vickery et al. shows that IgE and IgG4 binding to Ara $\mathrm{h}$ peanut proteins is modified by peanut OIT.

59.• Vickery B, Scurlock AM, Kulis M, Steele PH, Kamilaris J, Berglund JP, et al. Sustained unresponsiveness in subjects completing peanut oral immunotherapy. J Allergy Clin Immunol. 2014;133:468-75.

This is a seminal study that shows sustained unresponsiveness in peanut-allergic subjects using OIT, similar to [52•].

60. Sampson HA. Peanut oral immunotherapy: is it ready for clinical practice? J Allergy Clin Immunol. 2013;1:15-21.

An excellent review of the current evidence for efficacy of OIT in peanut-allergic subjects and its readiness for widespread clinical use.

61. Brozek JL, Terracciano L, Hsu J, Kreis J, Compalati E, Santesso N, et al. Oral immunotherapy for IgEmediated cow's milk allergy: a systematic review and meta-analysis. Clin Exp Allergy. 2012;42:36374 .
This meta-analysis critically reviews the published studies utilizing OIT for the treatment of milk allergy.

62. Pajno GB. Oral desensitization for milk allergy in children: state of the art. Curr Opin Allergy Clin Immunol. 2011;11:560-4.

63.• Nurmatov U, Devereaux G, Worth A, Healy L, Sheikh A. Effectiveness and safety of orally administered immunotherapy for food allergies: a systematic review and meta-analysis. Br J Nutr. 2014;111:12-22.

This meta-analysis reviews the available studies for use of OIT in the treatment of a variety of food allergies.

64. Yeung JP, Kloda LA, McDevitt J, Ben-Shoshan M, Alizadehfar R. Oral immunotherapy for milk allergy. Cochrane Database Syst Rev. 2012;11, CD009542.

Similar to [45•], this article by Yeung et al. is a meta-analysis of the use of OIT for the treatment of milk allergy.

65. Allam JP, Wurtzen PA, Reinartz M, Winter J, Vrtala S, Chen KW, et al. Phl p 5 resorption in human oral mucosa leads to dose-dependent and time-dependent allergen binding by oral mucosal Langerhans cells, attenuates their maturation, and enhances their migratory and TGF-beta1 and IL-10-producing properties. J Allergy Clin Immunol. 2010;126:638-45.

66. Mempel M, Rakoski J, Ring J, Ollert M. Severe anaphylaxis to kiwi fruit: immunologic changes related to successful allergen immunotherapy. J Allergy Clin Immunol. 2003;111:1406-9.

67. Kerzl R, Simonowa A, Ring J, Ollert M, Mempel M. Life-threatening anaphylaxis to kiwi fruit: protective sublingual allergen immunotherapy effect persists even after discontinuation. J Allergy Clin Immunol. 2007;119:507-8.

68. Enrique E, Pineda F, Malek T, Bartra J, Basagaña M, Tella R, et al. Sublingual immunotherapy for hazelnut food allergy: a randomized, double-blind, placebo-controlled study with a standardized hazelnut extract. J Allergy Clin Immunol. 2005;116:1073-9.

69. Fernandez-Rivas M, Garrido Fernandez S, Nadal JA, Alonso Diaz de Durana MD, Garcia BE, GonzalezMancebo E, et al. Randomized double-blind, placebo-controlled trial of sublingual immunotherapy with a Pru p 3 quantified peach extract. Allergy. 2009; 64:876-83.

70. Chin SJ, Vickery BP, Kulis MD, Kim EH, Varshney P, Steele $\mathrm{P}$, et al. Sublingual versus oral immunotherapy for peanut-allergic children: a retrospective comparison. J Allergy Clin Immunol. 2013;132:476-8.

This is another important article that directly compares OIT and SLIT, this time for treatment of peanut allergy.

71. Kim EH, Bird JA, Kulis M, Laubach S, Pons L, Shreffler W, et al. Sublingual immunotherapy for peanut allergy: clinical and immunologic evidence of desensitization. J Allergy Clin Immunol. 2011;127:640-6.

72. Fleischer DM, Burks AW, Vickery BP, Scurlock AM, Wood RA, Jones SM, et al. Sublingual immunotherapy for peanut allergy: a randomized, double-blind, 
placebo-controlled multicenter trial. J Allergy Clin Immunol. 2013;131:119-27.

73. Vila L, Beyer K, Jarvinen KM, Chatchatee P, Bardina L, Sampson HA. Role of conformational and linear epitopes in the achievement of tolerance in cow's milk allergy. Clin Exp Allergy. 2001;31:1599-606.

74. Urisu A, Ando H, Morita Y, Wada E, Yasaki T, Yamada $\mathrm{K}$, et al. Allergenic activity of heated and ovomucoid-depleted egg white. J Allergy Clin Immunol. 1997;100:171-6.

75. Nowak-Wegrzyn A, Bloom KA, Sicherer SH, et al. Tolerance to extensively heated milk in children with cow's milk allergy. J Allergy Clin Immunol. 2008;122:342-7.

76. Lemon-Mule H, Sampson HA, Sicherer SH, Shreffler WG, Noone S, Nowak-Wegrzyn A. Immunologic changes in children with egg allergy ingesting extensively heated egg. J Allergy Clin Immunol. 2008;122:977-83.

77. Kim JS, Nowak-Wegrzyn A, Sicherer SH, Noone S, Moshier EL, Sampson HA. Dietary baked milk accelerates the resolution of cow's milk allergy in children. J Allergy Clin Immunol. 2011;128:125-31.

78. Srivastava KD, Qu C, Zhang T, Goldfarb J, Sampson HA, Li XM. Food Allergy Herbal Formula-2 silences peanut-induced anaphylaxis for a prolonged post treatment period via IFN-gamma producing CD8+ T cells. J Allergy Clin Immunol. 2009;123:443-51.

79. Song Y, Qu C, Srivastava K, Yang N, Busse P, Zhao W, et al. Food allergy herbal formula 2 protection against peanut anaphylactic reaction in via inhibition of mast cells and basophils. J Allergy Clin Immunol. 2010;126:1208-17.

80. Patil SP, Wang J, Song Y, Noone S, Yang N, Wallenstein $S$, et al. Clinical safety of Food Allergy Herbal Formula-2 (FAHF-2) and inhibitory effect on basophils from patients with food allergy: extended phase I study. J Allergy Clin Immunol. 2011;128:1259-65.

81. MacGlashan DW, Bochner BS, Adelman DC, Jardieu PM, Togias A, McKenzie-White J, et al. Down-regulation of Fc(epsilon)RI expression on human basophils during in vivo treatment of atopic patients with anti-IgE antibody. J Immunol. 1997;158:1438-45.
82. Beck LA, Marcotte GV, MacGlashan D, Togias A, Saini $\mathrm{S}$. Omalizumab-induced reductions in mast cell Fc epsilon RI expression and function. J Allergy Clin Immunol. 2004;114:527-30.

83. Savage JH, Courneya JP, Sterba PM, MacGlashan DW, Saini SS, Wood RA. Kinetics of mast cell, basophil, and oral food challenge responses in omalizumab-treated adults with peanut allergy. J Allergy Clin Immunol. 2012;130:1123-9.

84. Nadeau KC, Schneider LC, Hoyte L, Borras I, Umetsu DT. Rapid oral desensitization in combination with omalizumab therapy in patients with cow's milk allergy. J Allergy Clin Immunol. 2011;127:1622-4.

85. Bedoret D, Singh AK, Shaw V, Hoyte EG, Hamilton R, DeKruyff RH, et al. Changes in antigen-specific T-cell number and function during oral desensitization in cow's milk allergy enabled with omalizumab. Mucosal Immunol. 2012;5:267-76.

86. Schneider LC, Rachid R, Lebovidge J, Blood E, Mittal M, Umetsu DT. A pilot study of omalizumab to facilitate rapid oral desensitization in high-risk peanutallergic patients. J Allergy Clin Immunol. 2013;132(6):1368-74.

87. Dioszeghy V, Mondoulet L, Dhelft V, Ligouis M, Puteaux E, Benhamou PH, et al. Epicutaneous immunotherapy results in rapid allergen uptake by dendritic cells through intact skin and downregulates the allergen-specific response in sensitized mice. J Immunol. 2011;186:5629-37.

88. Mondoulet L, Dioszeghy V, Vanoirbeek JA, Nemery B, Dupont C, Benhamou PH. Epicutaneous immunotherapy using a new epicutaneous delivery system in mice sensitized to peanuts. Int Arch Allergy Immunol. 2010;154:299-309.

89. Mondoulet L, Dioszeghy V, Larcher T, Ligouis M, Dhelft $\mathrm{V}$, Puteaux E, et al. Epicutaneous immunotherapy (EPIT) blocks the allergic esophago-gastroenteropathy induced by sustained oral exposure to peanuts in sensitized mice. PLoS One. 2012;7:e31967.

90. Dupont C, Kalach N, Soulaines P, et al. Cow's milk epicutaneous immunotherapy in children: a pilot trial of safety, acceptability, and impact on allergic reactivity. J Allergy Clin Immunol. 2010;125:1165-7. 